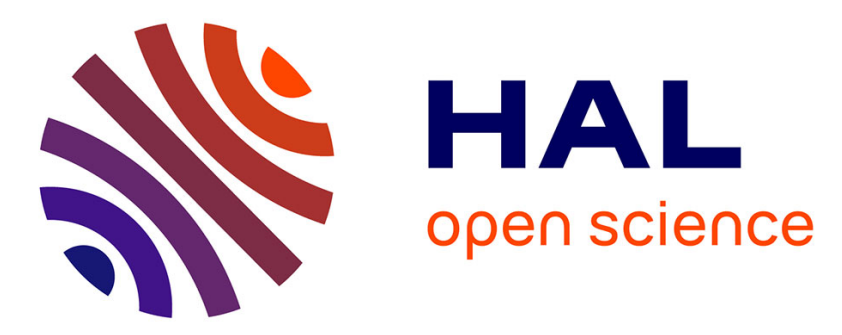

\title{
Is abdominal implantation of devices a good alternative to external attachment? A comparative study in Adélie penguins
}

\author{
Michaël Beaulieu, Yan Ropert-coudert, Yvon Maho, André Ancel
}

\section{- To cite this version:}

Michaël Beaulieu, Yan Ropert-coudert, Yvon Maho, André Ancel. Is abdominal implantation of devices a good alternative to external attachment? A comparative study in Adélie penguins. Journal für Ornithologie = Journal of Ornithology, 2010, 151 (3), pp.579-586. 10.1007/s10336-009-0491-2 . hal-00555322

\section{HAL Id: hal-00555322 \\ https://hal.science/hal-00555322}

Submitted on 13 Jan 2011

HAL is a multi-disciplinary open access archive for the deposit and dissemination of scientific research documents, whether they are published or not. The documents may come from teaching and research institutions in France or abroad, or from public or private research centers.
L'archive ouverte pluridisciplinaire HAL, est destinée au dépôt et à la diffusion de documents scientifiques de niveau recherche, publiés ou non, émanant des établissements d'enseignement et de recherche français ou étrangers, des laboratoires publics ou privés. 


\title{
Is abdominal implantation of devices a good alternative to external attachment? A comparative study in Adélie penguins
}

\author{
Michaël Beaulieu • Yan Ropert-Coudert • \\ Yvon Le Maho • André Ancel
}

Received: 3 June 2009/Revised: 20 October 2009/Accepted: 21 December 2009/Published online: 13 January 2010

(c) Dt. Ornithologen-Gesellschaft e.V. 2010

\begin{abstract}
Bio-logging studies suffer from the lack of real controls. However, it is still possible to compare indirect parameters between control and equipped animals to assess the level of global disturbance due to instrumentation. In addition, it is also possible to compare the behaviour of free-ranging animals between individuals equipped with different techniques or instruments to determine the less deleterious approach. We instrumented Adélie Penguins (Pygoscelis adeliae) with internal or external time-depth recorders and monitored them in parallel with a control group during the first foraging trip following instrumentation. Foraging trip duration was significantly longer in the internally-equipped group. This difference was due to a larger number of dives, reflecting a lower foraging ability or a higher food demand, and longer periods of recovery at the surface. These longer recovery periods were likely to be due to a reduced efficiency to ventilate at the surface, probably because the implanted devices pressurised adjacent organs such as air sacs. Moreover, descent and ascent rates were slightly lower in externally-equipped penguins, presumably because external instrumentation increased the bird drag. Looking at our results, implantation appears more disadvantageous-at least for short-term deployment-than external equipment in Adélie Penguins, while this method has been described to induce no negative effects in long-term studies. This underlines the need to control for potential effects due to methodological aspects
\end{abstract}

Communicated by P.H. Becker.

M. Beaulieu $(\bowtie) \cdot$ Y. Ropert-Coudert · Y. Le Maho · A. Ancel Département Ecologie, Physiologie et Ethologie (DEPE), Institut Pluridisciplinaire Hubert Curien (IPHC),

UMR 7178 CNRS-UDS, 23 rue Becquerel,

67087 Strasbourg Cedex 2, France

e-mail: michael.beaulieu@c-strasbourg.fr in any study using data loggers in free-ranging animals, to minimise disturbance and collect reliable data.

Keywords Bio-logging · Diving behaviour . Implantation $\cdot$ Penguins

\section{Introduction}

For more than three decades, bio-logging has permitted the exploration of many ecological, physiological and behavioural aspects of animal biology in the wild, where animals could not otherwise be monitored (Ropert-Coudert and Wilson 2005). However, attaching instruments to wild animals can sometimes have unexpected adverse effects. For instance, in diving animals, some studies indicated that instrumentation may affect foraging trip duration (Wanless et al. 1988; Croll et al. 1991; Hull 1997; Taylor et al. 2001), body mass loss (Elliott et al. 2007), provisioning rate, offspring growth and breeding success (Watanuki et al. 1992; Croll et al. 1996; Ackerman et al. 2004). However, researchers rarely consider the actual impact of instrumentation on the performances of free-ranging animals and usually presume that handling effects are minor (Hawkins 2004; Wilson and McMahon 2006). The reason for this may be inherent to the impossibility to monitor a control group in the wild. There does not seem to be an ideal solution to solve this problem since at-sea monitoring implies equipping animals with devices and "measurement affects performance" (Wilson et al. 1986). Nevertheless, considering that an instrumented animal is always more or less disturbed, a solution consists in equipping two groups with differently-sized, shaped or attached instruments and comparing behaviours between groups (Wilson et al. 1986; Elliott et al. 2007; Ropert-Coudert et al. 2007). Such an 
approach, used in combination with the aforementioned indirect parameters collected on land, should suffice to evaluate the effects of instrumentation on animal behaviour.

In diving birds, the deleterious effects of instrument attachment are generally attributed to the disruption of the animals' streamlined body shape (Williams and Kooyman 1985; Lovvorn et al. 2001) prompting some to propose internal implantation of devices in the body cavity as an alternative method to externally-attached equipment. This technique has been used successfully to collect data in several studies among which are long-term studies that report no negative impact of instrumentation (Guillemette et al. 2002; Green et al. 2004; Grémillet et al. 2005). Surprisingly, instrument implantation did not receive as much attention as external equipment, and studies dealing with the impacts of implanted devices remain scarce (but see Guillemette et al. 2002; Green et al. 2004; Small et al. 2004). Yet internal implantation may induce deleterious effects such as pain, inflammation, irritation, interference with physiological functions, tissue damage and an increase in the cost of locomotion (Hawkins 2004).

In this work, we investigated the potential impact of equipment in free-ranging Adélie penguins (Pygoscelis adeliae). We evaluated this impact, first indirectly, via a measure of the foraging trip duration of control, externallyequipped and internally-equipped birds, then, more directly via a comparison of the diving behaviour of penguins internally or externally equipped with time-depth recorders. This parallel study on external and internal equipment aims to assess the global level of disturbance of both methods relative to control birds and the potential effects of one technique relative to the other on diving behaviour.

\section{Methods}

The study took place at the French station Dumont d'Urville $\left(66^{\circ} 40^{\prime} \mathrm{S}, 140^{\circ} 01^{\prime} \mathrm{E}\right)$, Adélie Land, Antarctica, during the austral summer 2007-2008. The experimental group of penguins was constituted by 19 pairs: 11 pairs with no equipment forming the control group, 5 externallyequipped pairs ("external" group) and 3 internally-equipped pairs ("internal" group).

\section{Equipment}

During courtship, externally-equipped females were instrumented with time-depth recorders (IPHC, Strasbourg, France; $30 \mathrm{~g}, 50 \times 26 \times 15 \mathrm{~mm}, n=10$ ) attached to their lower back with mastic and marine Tesa ${ }^{\circledR}$ tape (Wilson et al. 1997). Externally-equipped males $(n=5)$ and internally-equipped birds $(n=6)$ were instrumented with the same loggers during incubation. Males were equipped or implanted 7 days after egg laying and females' departure to sea to avoid adverse effects of early equipment on hatching success (Beaulieu et al. in press). Females were implanted 2 days after returning from their first foraging trip when their mate was at sea to feed. Consequently, males were monitored during their first foraging trip and females during their second foraging trip. The delay between the implantation and the subsequent departure to sea was $5.7 \pm 1.2$ days (mean $\pm \mathrm{SD}$ ) for males and $16.7 \pm 2.0$ days (mean $\pm \mathrm{SD}$ ) for females. A period of a few days is generally admitted to be sufficient for the birds to recover and for the tissues to heal (Ropert-Coudert et al. 2000; Bevan et al. 2002; Green et al. 2004).

Surgery was performed by veterinarians under strict conditions of sterility and after approval of the ethics committee of the French Polar Institute. Before implanting devices, birds were anaesthetised with Isoflurane (ForeneND; maintained between 1.5 and 2.5\%) and breathed spontaneously. On the right side of the brood patch, some feathers were removed to sterilise the surgical area. Internal loggers, coated in wax and bio-medical silicone (Silastic; Dow Corning, Midland, MI, USA), were implanted into the abdomen. Devices were secured within the abdominal cavity by anchoring them to the abdominal muscle layer with sutures. Muscles, subcutaneous tissue and skin were then sutured. Antibiotics (Oxytetracyclin, Terramycine LA, $20 \mathrm{mg} / \mathrm{kg}$ ) and anti-inflammatory (ketoprofen, Ketofen $1 \% \mathrm{ND}, 2 \mathrm{mg} / \mathrm{kg}$ ) were injected before birds came to consciousness. Sedation and surgery lasted $01 \mathrm{~h} 39 \pm 17$ min (mean $\pm \mathrm{SD}, n=6$ ). During surgery, eggs were artificially incubated at $35^{\circ} \mathrm{C}$. Birds were released after implantation on their nest on dummy plaster eggs so that real eggs were not broken. When they completely regained consciousness and exhibited normal brooding behaviour, dummy eggs were replaced by their own eggs. Instruments were recovered after one foraging trip following the same procedure as that described for equipment.

\section{On-land monitoring}

During courtship, experimental penguins were identified with a Nyanzol-D mark painted on breast feathers. To estimate foraging trip duration, the presence on nest of every experimental bird was checked every $2 \mathrm{~h}$ during the study period.

\section{At-sea monitoring}

The loggers recorded depth every $5 \mathrm{~s}$. After the recovery of devices, data were downloaded and analysed using IGOR software (Wavemetrics, version 5.0, USA). Only 
dives $>1 \mathrm{~m}$ were included in the analyses. In total, 81,018 dives were recorded. The start and end of the bottom phase of each dive were defined as the first and the last time the rate of change of depth became $<0.25 \mathrm{~m} \mathrm{~s}^{-1}$ during a dive. The end of diving bouts was calculated according to the method of Gentry and Kooyman (1986).

\section{Statistical analysis}

Foraging trip durations were compared between the three treatment groups using generalised linear models (GLM) with the treatment (control, internal, external), the sex and their interactions as fixed factors. The time and the percentage of time spent underwater per foraging trip were compared between internally- and externally-equipped birds, with GLM including the treatment and the sex as fixed factors. For the number of dives, the comparison was carried out with a GLM with a Poisson distribution. Analyses of diving behaviour were conducted on the following dive parameters: maximum dive depth $(\mathrm{m})$, dive duration (s), descent duration (s), descent rate $\left(\mathrm{m} \mathrm{s}^{-1}\right)$, bottom duration (s), number of undulations during the bottom phase (an index of feeding success; Bost et al. 2007), ascent duration (s), ascent rate $\left(\mathrm{m} \mathrm{s}^{-1}\right)$ and postdive duration (s). To compare diving behaviour between the two groups, we used mixed models to avoid the problem of pseudoreplication since our statistical analyses involved repeated observations of the same subjects. Individuals were considered as random factors while the treatment, the sex and their interaction were used as fixed factors. In addition, since the maximum depth during a dive influences all other dive parameters $(P<0.001$ in all tests), we added it as a covariate in the model. When the model gave a significant result for a given parameter, to examine the influence of depth on this parameter, we performed the same model but with the maximum depth class as a fixed factor; for this, we used 20, 40, 60, 80 and $100 \mathrm{~m}$ as depth classes. Multiple comparisons were undertaken using the post-hoc Tukey test. Analyses were conducted using JMP 8 (SAS Institute). Results are expressed as means \pm SE and significance level was set at $\alpha=0.05$.

\section{Results}

Foraging trip duration

Foraging trip duration differed between males and females $\left(F_{1,32}=727.54, P<0.001\right)$ and between the different treatment groups $\left(F_{2,32}=51.12, P<0.001\right)$. Penguins from the control group performed foraging trips as long as those performed by externally-equipped penguins $(P>0.99)$ but foraging trips performed by internallyequipped birds were 1.5 times as long as those of controls $(P=0.001)$ and externally-equipped birds $(P=0.001)$. The same trend was obtained in males and females (interaction $\operatorname{sex} \times$ treatment, $F_{2,32}=2.52, \quad P=0.10$; Fig. 1).

Number of dives and time underwater per foraging trip

Externally-equipped birds dove less frequently per foraging trip and spent relatively more time underwater than internallyequipped birds (number of dives: 4,237 \pm 19 and $5,366 \pm 28$, respectively; Wald $\chi_{1}^{2}=1,316, P<0.001$, percentage of time underwater: $39 \pm 10$ and $26 \pm 6 \%$ of foraging trip duration, respectively; $F_{1,13}=12.39$, $P=0.004)$. However, total time spent underwater did not significantly differ between the two groups (external: $70 \pm 5 \mathrm{~h}$; internal: $\left.82 \pm 7 \mathrm{~h} ; F_{1,13}=2.04, P=0.18\right)$.
Fig. 1 Foraging trip duration (mean $\pm \mathrm{SE}$ ) of control $(n=22)$, externally- $(n=10)$ and internally-equipped $(n=6)$ Adélie penguins (Pygoscelis adeliae). The first foraging trip of males (black) and the second foraging trip of females after laying (grey) are represented. Different letters indicate significant differences between treatment groups

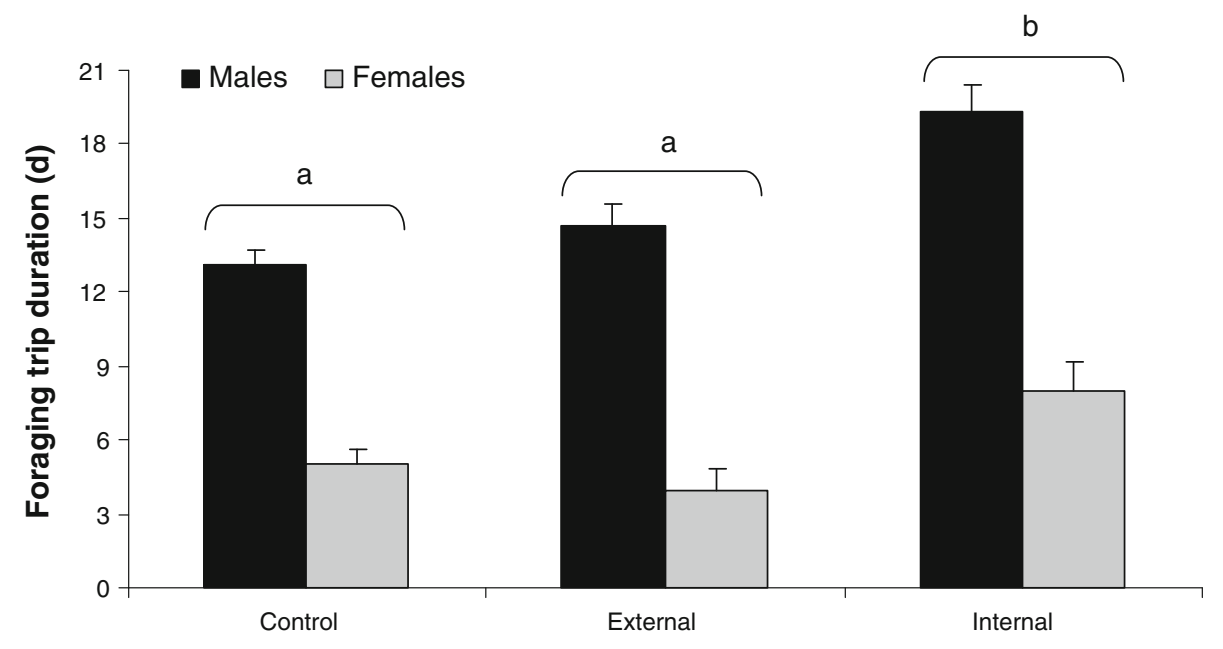


Table 1 Diving parameters of externally- $(n=10)$ and internallyequipped $(n=6)$ Adélie penguins (Pygoscelis adeliae) (mean $\pm \mathrm{SE}$ )

\begin{tabular}{lrcll}
\hline & External device & Internal device & $F$ & \multicolumn{1}{l}{$P$} \\
\hline Maximum depth (m) & $21.03 \pm 1.52$ & $17.16 \pm 1.96$ & 2.41 & 0.15 \\
Dive duration $^{\mathrm{a}}(\mathrm{s})$ & $58.65 \pm 1.48$ & $58.21 \pm 1.9$ & 0.03 & 0.86 \\
Descent duration $^{\mathrm{a}}(\mathrm{s})$ & $19.48 \pm 0.54$ & $18.72 \pm 0.7$ & 0.74 & 0.41 \\
Descent rate $^{\mathrm{a}}\left(\mathrm{m} \mathrm{s}^{-1}\right)$ & $\mathbf{0 . 7 1} \pm \mathbf{0 . 0 2}$ & $\mathbf{0 . 7 8} \pm \mathbf{0 . 0 2}$ & $\mathbf{5 . 7 6}$ & $\mathbf{0 . 0 3}$ \\
Bottom duration $^{\mathrm{a}}(\mathrm{s})$ & $17.68 \pm 1.06$ & $19.04 \pm 1.33$ & 0.71 & 0.44 \\
Number of undulations $^{\mathrm{a}}$ & $1.76 \pm 0.05$ & $1.89 \pm 0.07$ & 2.20 & 0.17 \\
Ascent duration $^{\mathrm{a}}(\mathrm{s})$ & $21.47 \pm 0.43$ & $20.45 \pm 0.55$ & 2.06 & 0.17 \\
Ascent rate $^{\mathrm{a}}\left(\mathrm{m} \mathrm{s}^{-1}\right)$ & $\mathbf{0 . 6 5} \pm \mathbf{0 . 0 1}$ & $\mathbf{0 . 7 1} \pm \mathbf{0 . 0 2}$ & $\mathbf{8 . 5 9}$ & $\mathbf{0 . 0 1}$ \\
Post-dive duration $^{\mathrm{a}}(\mathrm{s})$ & $\mathbf{2 2 . 2 0} \pm \mathbf{0 . 7 6}$ & $\mathbf{2 5 . 8 9} \pm \mathbf{0 . 9 8}$ & $\mathbf{7 . 6 4}$ & $\mathbf{0 . 0 2}$
\end{tabular}

Significant differences between the two groups of birds are in bold

a Annotated parameters were calculated with maximum depth as a covariate.

\section{Diving behaviour}

The sex had an effect on the maximum depth $\left(F_{1,12}=7.42\right.$, $P=0.02)$ with males diving deeper $(22.5 \pm 1.8 \mathrm{~m})$ than females $(15.7 \pm 1.7 \mathrm{~m})$. All other diving parameters were similar between males and females (all $P>0.11$ ).

The method of equipment (external vs. internal) had no effect on almost all the considered dive parameters: dive duration, maximum depth, descent duration, bottom duration, number of undulations and ascent duration (Table 1). However, descent and ascent rates were both $\sim 10 \%$ lower in externally-equipped birds than in internally-equipped penguins. Finally, internally-equipped birds spent more time at the surface between two consecutive dives than externally-equipped birds (Table 1). None of the diving parameters was affected by the interaction sex $\times$ treatment (all $P>0.05$ ).

The interaction treatment $\times$ depth class was significant for descent rate $\left(F_{1,78819}=284.56, P<0.001\right)$ and ascent rate $\left(F_{1,74496}=234.91, P<0.001\right)$. However, multiple comparisons for each depth class gave significant results only for ascent rate with lower values for deep dives in externally-equipped penguins (Fig. 2). The interaction treatment $\times$ depth class was also significant for post-dive duration $\left(F_{1,71575}=332.80, P<0.001\right)$ with longer surface time for deep dives in implanted penguins (Fig. 2).

\section{Discussion}

Overall, externally-equipped penguins were less affected by the devices than internally-implanted birds whose foraging trips were 1.5 times as long as those of controls. Three non-exclusive hypotheses may explain why their foraging trips were lengthened: (1) internally-equipped birds may have been less efficient underwater so that they needed more time to catch a certain amount of prey, (2) the implantation induced an extra energetic cost associated with tissue repair and penguins may compensate for this energetic debt by foraging longer to catch more prey, and (3) implanted penguins needed more time to recover at the surface.

Our results gave support to these three hypotheses. Implanted birds performed more dives than externallyequipped penguins suggesting that they had reduced foraging ability and that they had to perform additional dives to reach a certain level of caught preys (hypothesis 1) and/ or they had to compensate for the extra-cost incurred by implantation (hypothesis 2). However, they did not alter the characteristics of their dives. Only the descent and the ascent rates differed between implanted and externallyequipped penguins. This difference is rather due to a loss of hydrodynamics of externally-equipped penguins. For external equipment, the consensus recommends attaching small (the device should have a maximum cross-sectional area of $1 \%$ of that of the penguin; Culik and Wilson 1991), streamlined instruments on the lower back of animals (Bannasch et al. 1994) to minimise the extra drag due to the instrument. In our study, the device cross-sectional area represented $2-2.5 \%$ of that of the penguins and may explain why externally-equipped birds were slightly restrained during the transit phases of dive. This disadvantage was more important for deep dives for ascent rate but not for descent rate. Contrary to the descent phase which is associated with active flipper beating (Sato et al. 2002), the ascent phase is passive and therefore seems to be more affected by an extra drag in the case of deep dives.

Implanted penguins were more streamlined than externally-equipped penguins, which corresponds precisely to the expected benefit of implantation versus external attachment. However, they had to recover from diving for a longer time (hypothesis 3): post-dive duration was $\sim 4 \mathrm{~s}$ (17\%) longer in implanted penguins than in externallyequipped birds and this was worsened by deep dives. It is likely that this difference would even be more important between implanted penguins and control penguins (with no equipment) since externally-equipped penguins were slightly restrained during the transit phases of dive. The time at the surface between consecutive dives depends on the degree to which the body must be loaded with oxygen (Butler and Jones 1997). The most important way to save oxygen while diving is to reduce oxygen requirements by a reduction of metabolism (Ramirez et al. 2007). It may be first hypothesised that implanted birds' metabolism was increased because of the inflammatory and the woundhealing responses following implantation. In this line of thought, it has been reported that a simple midline exploratory laparotomy, with no implantation, increases the post-operative caloric demand by $10 \%$ in horses 
Fig. 2 Descent rate, ascent rate and post-dive duration (mean $\pm \mathrm{SE}$ ) as a function of maximum depth. *Significant difference between penguins equipped with internal (black symbols) and external (grey symbols) instruments for a given depth class
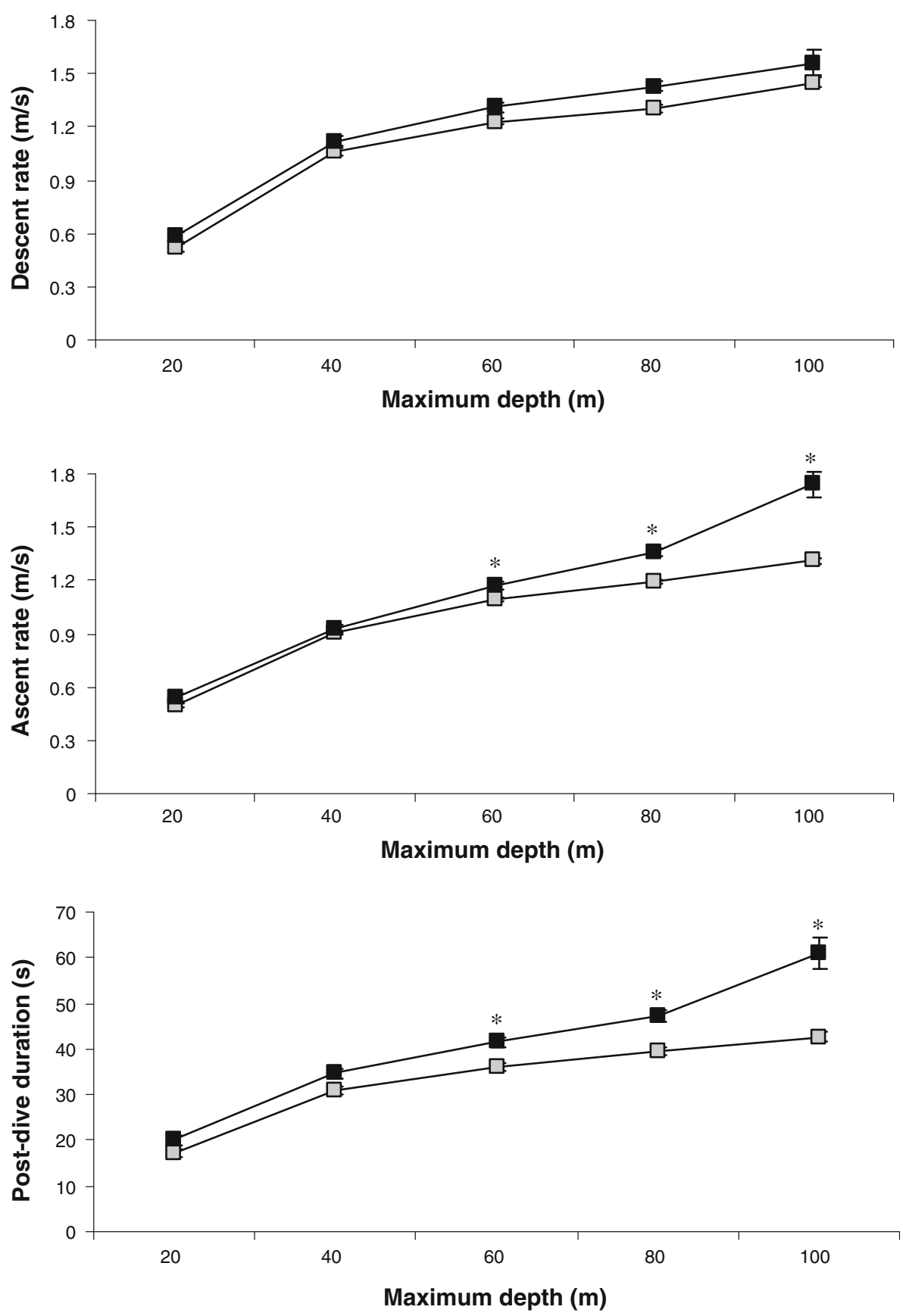

(Cruz et al. 2006). In our study, although the skin incision was totally clean and completely healed before device recovery, a fibrous capsule was found around the loggers indicating the occurrence of an inflammatory response (Anderson et al. 2008). However, the presence of this capsule has not been associated with physiological or behavioural deleterious effects in previous studies (Small et al. 2004; Mulcahy et al. 2007). A more probable reason of the extended recovery surface intervals is that the device (volume: $\sim 20 \mathrm{~cm}^{3}$ ) may have pressurised adjacent organs such as air sacs (Small et al. 2004), thus reducing the birds' efficiency to ventilate at the surface.
Culik and Wilson (1991) found that the cost of transport of implanted Adélie penguins swimming in a water canal was lower than that of externally-equipped penguins (Fig. 3). However, diving is not possible in such a setting and their measurements do not reflect what happens in the wild, especially since distances and depths covered largely differ. These measurements are therefore not comparable to device-induced effects in free-ranging animals. Another study by Ropert-Coudert et al. (2000) only included implanted king penguins (Aptenodytes patagonicus) with or without external devices. With such a design, the effects of both techniques were mixed up and the effects of 
Fig. 3 Proportion of the volume of the implanted device relative to the body mass of birds in studies having assessed the impact of implantation.

${ }^{1}$ Unpublished data (A. Ancel, personal communication), ${ }^{2}$ Bevan et al. (2002), ${ }^{3}$ Culik and Wilson (1991), ${ }^{4}$ Green et al. (2004), ${ }^{5}$ Grémillet et al. (2005), ${ }^{6}$ this study, ${ }^{7}$ Guillemette et al. (2002), ${ }^{8}$ Mulcahy et al. (2007), ${ }^{9}$ Meyers et al. (1998). Black bars refer to studies showing an effect of implantation, while white bars indicate no apparent effect. The parameters measured are indicated above each study $(\uparrow$ increased parameter, $\downarrow$ decreased parameter, $=$ unchanged parameter)

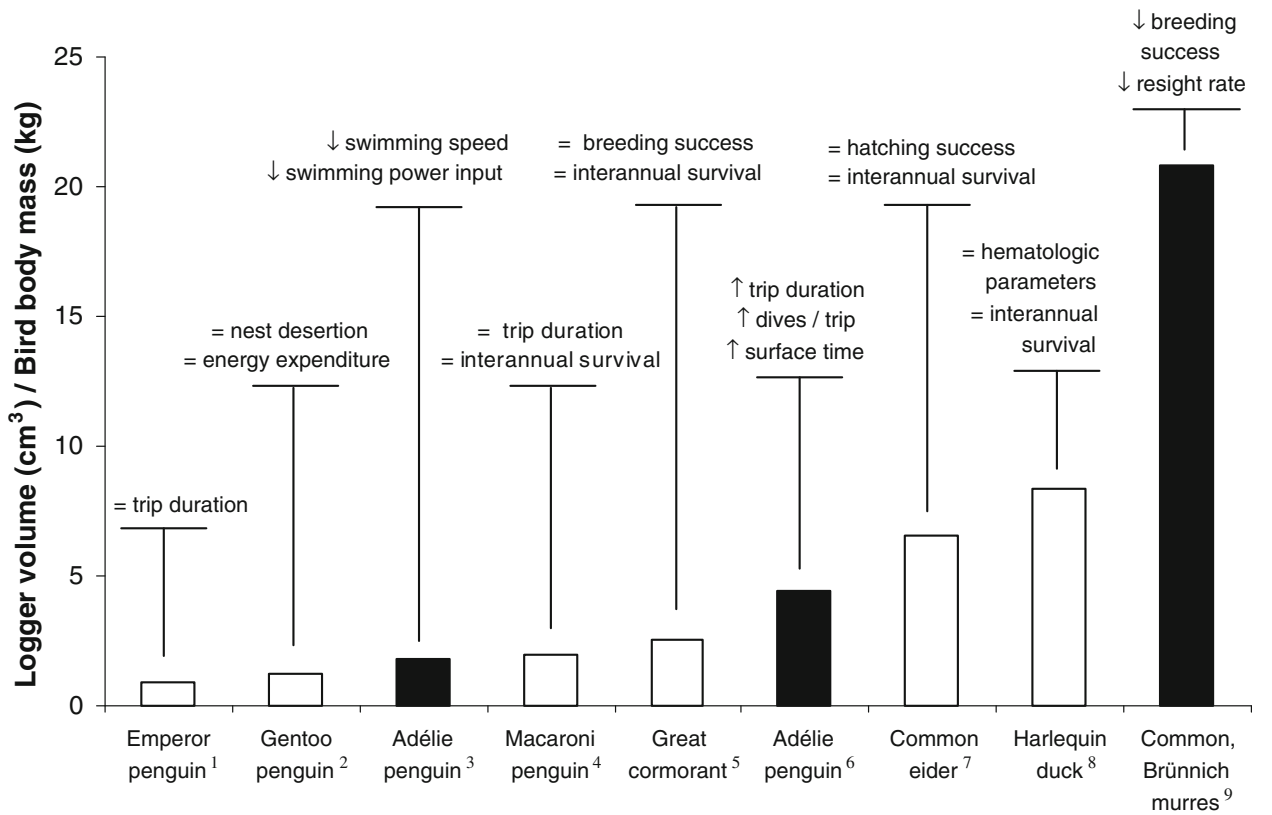

implantation could not be assessed. Finally, Green et al. (2004) found no differences between free-ranging control and implanted macaroni penguins (Eudyptes chrysolophus) and, in contrast to our study, foraging trip duration was not lengthened in implanted birds (Fig. 3). One reason may be that the volume of the device used by Green et al. (2004) was smaller than ours (11 vs. $20 \mathrm{~cm}^{3}$ ). In addition, this difference may have been accentuated by the size of the penguins since macaroni penguins are larger $(5-6 \mathrm{~kg}$; Reilly 1994) than Adélie penguins (4-5 kg), so that the proportion of the logger relative to the penguin size or body mass was smaller in Green's study than in ours (Fig. 3). However, the proportion of the implanted device relative to the body mass of birds was not excessive in our study compared to other studies (Fig. 3). Moreover, some studies with devices larger than ours (relative to the birds' body mass) did not report any effects of the implantation procedure. Yet the parameters measured to assess the impact of implantation vary between the different studies (Fig. 3), making the comparisons difficult.

In our study, implantation appeared more disadvantageous for Adélie penguins than external attachment (even though this latter method also induced some disadvantages). However, our study did not allow us to distinguish the related effects of each step of the implantation procedure: anaesthesia (Machin and Caulkeet 2000), laparotomy and implantation itself. To separate the effects of the surgery from the effects of implantation, another control group on which surgery would be performed but without implantation would be worthwhile.

External and internal loggers being the same size and internal loggers being more disadvantageous for penguins, it suggests that the miniaturisation of internal loggers is even more important than that of external loggers. This emphasises the importance to control for the potential effects that any methodological approach may trigger in instrumented free-ranging animals. Finally, it is the researcher's responsibility to evaluate and communicate information related to methodological refinement to reduce animal discomfort (Hawkins 2004) and to minimise the bias due to methodology on collected data. There is still, nonetheless, no satisfying alternative to implantation for long-term deployment that span periods up to a year (see Grémillet et al. 2005). The choice between implantation and external attachment should finally depend on the duration of device deployment.

\section{Zusammenfassung}

Ist die abdominale Implantation von Geräten eine gute Alternative zu ihrer äußeren Befestigung? Eine vergleichende Studie an Adeliepinguinen

Bio-Logging-Studien leiden darunter, dass echte Kontrollen fehlen. Es ist jedoch dennoch möglich, indirekte Parameter zwischen Kontrolltieren und ausgerüsteten Tieren zu vergleichen, um das Ausmaß der globalen Beeinträchtigung durch die Instrumentierung abzuschätzen. Zusätzlich ist es möglich, das Verhalten wildlebender Tiere zu vergleichen, die mit unterschiedlicher Technik oder Instrumenten ausgestattet wurden, um den am wenigsten schädlichen Ansatz zu ermitteln. Wir haben Adeliepinguine mit internen oder externen Zeit-TiefenRekordern ausgestattet und sie parallel zu einer Kontrollgruppe während des ersten Nahrungssuchtrips nach der 
Instrumentierung überwacht. Die Dauer des Nahrungssuchtrips war für die intern ausgerüstete Gruppe signifikant länger. Dieser Unterschied war einer größeren Anzahl von Tauchgängen, was ein geringeres Nahrungssuchvermögen oder einen höheren Nahrungsbedarf anzeigen könnte, sowie längeren Erholungsphasen an der Wasseroberfläche zuzuschreiben. Diese längeren Erholungsphasen waren wahrscheinlich auf eine verminderte Fähigkeit, an der Oberfläche zu atmen, zurückzuführen, vermutlich da die implantierten Geräte auf angrenzende Organe wie Luftsäcke drückten. Darüber hinaus waren die Raten von Ab- und Auftauchen bei extern ausgerüsteten Pinguinen etwas niedriger, da die externe Instrumentierung vermutlich den Wasserwiderstand des Vogels erhöhte. Unsere Ergebnisse deuten darauf hin, dass_-zumindest für den kurzzeitigen Einsatz-die Implantation bei Adeliepinguinen nachteiliger ist als die externe Ausstattung obwohl beschrieben wurde, dass diese Methode keine negativen Effekte in Langzeitstudien hat. Dies unterstreicht die Notwendigkeit, in jeder Studie, die Datenlogger bei wildlebenden Tieren einsetzt, für mögliche methodologische Effekte zu kontrollieren, um Beeinträchtigungen zu minimieren und verlässliche Daten zu sammeln.

Acknowledgments This study was approved and supported by the French Polar Institute Paul Emile Victor (IPEV) and the Terres Australes et Antarctiques Françaises (TAAF). We would like to thank the Département de Recherches Subatomiques team for the conception of data loggers. We are also grateful to F. Baudimont and G. Chanet for their essential help during surgical procedures. Finally, we also have to thank A. M. Thierry for field assistance and Dr. A. Kato for her help with Igor and JMP software.

\section{References}

Ackerman J, Adams J, Takekawa JY, Carter HR, Whitworth DL, Newman SH, Golightly RT, Orthmeyer DL (2004) Effects of radiotransmitters on the reproductive performance of Cassin's auklets. Wildl Soc Bull 32:1229-1241

Anderson JM, Rodriguez A, Chang DT (2008) Foreign body reaction to biomaterials. Semin Immunol 20:86-100. doi:10.1016/j. smim.2007.11.004

Bannasch R, Wilson RP, Culik BM (1994) Hydrodynamic aspects of design and attachment of a back-mounted device in penguins. J Exp Biol 194:83-96

Beaulieu M, Thierry A-M, Handrich Y, Le Maho Y, Massemin S, Ancel A (in press) Adverse effects of instrumentation in incubating Adélie penguins. Polar Biol. doi:10.1007/s00300009-0725-Z

Bevan RM, Butler PJ, Woakes AJ, Boyd IL (2002) The energetics of gentoo penguins, Pygoscelis papua, during the breeding season. Funct Ecol 16:175-190

Bost CA, Handrich Y, Butler PJ, Fahlman A, Halsey LG, Woakes AJ, Ropert-Coudert Y (2007) Changes in dive profiles as an indicator of feeding success in king and Adelie penguins. Deep Sea Res Part II 54:248-255. doi:10.1016/j.dsr2.2006.11.007

Butler PJ, Jones DR (1997) Physiology of diving of birds and mammals. Physiol Rev 77:837-899
Croll DA, Osmek SD, Bengtson JL (1991) An effect of instrument attachment on foraging trip duration in chinstrap penguins. Condor 93:777-779

Croll DA, Jansen JK, Goebel ME, Boveng PL, Bengtson JL (1996) Foraging behaviour and reproductive success in chinstrap penguins: the effects of transmitter attachment. J Field Ornithol 67:1-9

Cruz AM, Coté N, McDonell WN, Geor RJ, Wilson BA, Monteith G, Li R (2006) Postoperative effects of anesthesia and surgery on resting energy expenditure in horses as measured by indirect calorimetry. Can J Vet Res 70:257-262

Culik BM, Wilson RP (1991) Energetics of underwater swimming in Adélie penguins (Pygoscelis adeliae). J Comp Physiol 161:285291

Elliott KH, Davoren GK, Gaston AJ (2007) The influence of buoyancy, and drag on the dive behaviour of an arctic seabird, the thick-billed murre. Can J Zool 85:352-361. doi:10.1139/Z07-012

Gentry RL, Kooyman GL (1986) Fur seals: maternal strategies on land and at sea. Princeton University Press, Princeton

Green JA, Tanton JL, Woakes AJ, Boyd IL, Butler PJ (2004) Effects of long-term implanted data loggers on macaroni penguins Eudyptes chrysolophus. J Avian Biol 35:370-376

Grémillet D, Kuntz G, Woakes AJ, Gilbert C, Robin JP, Le Maho Y, Butler PJ (2005) Year-round recordings of behavioural and physiological parameters reveal the survival strategy of a poorly insulated diving endotherm during the arctic winter. J Exp Biol 208:4231-4241. doi:10.1242/jeb.01884

Guillemette M, Woakes AJ, Flagstad A, Butler PJ (2002) Effects of data-loggers implanted for a full year in female common eiders. Condor 104:448-452. doi:10.1650/0010-5422(2002)104

Hawkins P (2004) Bio-logging and animal welfare: practical refinements. Mem Natl Inst Polar Res 58:58-68

Hull CL (1997) The effect of carrying devices on breeding royal penguins. Condor 99:530-534

Lovvorn J, Liggins GA, Borstad MH, Calisal SM, Mikkelsen J (2001) Hydrodynamic drag of diving birds: effects of body size, body shape and feathers at steady speeds. J Exp Biol 204:1547-1557

Machin KL, Caulkeet NA (2000) Evaluation of isoflurane and propofol anesthesia for intra-abdominal transmitter placement in nesting canvasback ducks. J Wildl Dis 36:324-334

Meyers PM, Hatch SA, Mulcahy DM (1998) Effects of implanted satellite transmitters on the nesting behavior of murres. Condor 100:172-174

Mulcahy DM, Burek KA, Esler D (2007) Inflammatory reaction to fabric collars from percutaneous antennas attached to intracoelomic radio transmitters implanted in harlequin ducks (Histrionicus histrionicus). J Avian Med Surg 21:13-21

Ramirez JM, Folkow LP, Blix AS (2007) Hypoxia tolerance in mammals and birds: from the wilderness to the clinic. Annu Rev Physiol 69:113-143. doi:10.1146/annurev.physiol.69.031905. 163111

Reilly P (1994) Penguins of the world. Oxford University Press, Melbourne

Ropert-Coudert Y, Wilson RP (2005) Trends and perspectives in animal-attached remote-sensing. Front Ecol Environ 3:437-444

Ropert-Coudert Y, Bost CA, Handrich Y, Bevan RM, Butler PJ, Woakes AT, Le Maho Y (2000) Impact of externally attached loggers on the diving behaviour of the king penguin. Physiol Biochem Zool 73:438-445

Ropert-Coudert Y, Wilson RP, Yoda K, Kato A (2007) Assessing performance constraints in penguins with externally-attached devices. Mar Ecol Prog Ser 333:281-289

Sato K, Naito Y, Kato A, Niizuma Y, Watanuki Y, Charrassin JB, Bost CA, Handrich Y, Le Maho Y (2002) Buoyancy and maximal diving depth in penguins: do they control inhaling air volume? J Exp Biol 205:1189-1197 
Small MF, Rosales R, Baccus JT, Weckerly FW, Phalen DN, Roberson JA (2004) A comparison of effects of radiotransmitter attachment techniques on captive white-winged doves. Wildl Soc Bull 32:627-637. doi:10.2193/0091-7648(2004)032

Taylor SS, Leonard ML, Boness DJ, Majluf P (2001) Foraging trip duration increases for Humboldt penguins tagged with recording devices. J Avian Biol 32:369-372

Wanless S, Harris MP, Morris JA (1988) The effect of radio transmitters on the behaviour of common murres and razorbills during chick rearing. Condor 90:816-823

Watanuki Y, Mori Y, Naito Y (1992) Adélie penguin parental activities and reproduction: effects of device size and timing of its attachment during chick rearing period. Polar Biol 12:539-544
Williams TM, Kooyman GL (1985) Swimming performance and hydrodynamic characteristics of harbor seals Phoca vitulina. Physiol Zool 58:576-589

Wilson RP, McMahon CR (2006) Measuring devices on wild animals: what constitutes acceptable practice? Front Ecol Environ 4:147154

Wilson RP, Grant WS, Duffy DS (1986) Recording devices on freeranging marine animals: does measurement affect foraging performance. Ecology 67:1091-1093

Wilson RP, Pütz K, Peters G, Culik BM, Scolaro JA, Charrassin JB, Ropert-Coudert Y (1997) Long-term attachment of transmitting and recording devices to penguins and other seabirds. Wildl Soc Bull 25:101-106 